\title{
LOS REQUENA, UNA ENIGMÁTICA FAMILIA DE PINTORES DEL RENACIMIENTO. A PROPÓSITO DE GASPAR REQUENA EL JOVEN
}

\author{
POR \\ Albert Ferrer Orts y CARmen Aguilar Díaz \\ Universitat de València
}

Las recientes exposiciones que viene realizando la Fundación "La Luz de las Imágenes” en el ámbito de las distintas diócesis valencianas no sólo ha acercado al público numerosas obras de arte en condiciones de ser vistas y admiradas, sino que también ha posibilitado su estudio. En ese contexto presentamos un acercamiento al taller de los Requena; una familia de pintores activa en el Reino de Valencia entre $1531 \mathrm{y}$ 1605 aproximadamente que, en su desigual producción, deja entrever las innegables deudas con Paolo da San Leocadio, los Hernandos y, particularmente, Joan de Joanes.

Palabras clave: los Requena; Pintores; Reino de Valencia; S. XVI; Paolo da San Leocadio; los Hernandos; Joan de Joanes.

Recent exhibitions produced by the Foundation La Luz de las Imágenes in Valencian dioceses has allowed for numerous works of art to be seen, admired and studied under optimal conditions. In this context we offer an approach to the workshop of the Requena family, painters active in the Kingdom of Valencia between approximately 1531 and 1605. These artists, in their uneven production, owed much to Paolo da San Leocadio, the Hernandos and particularly, Joan de Joanes.

Key words: the Requena; Painters; Valencia; $16^{\text {th }}$ century; Paolo da San Leocadio; the Hernandos; Joan de Joanes.

Desde que Fernando Benito asociara a Vicente Requena el Joven (Valencia, 1556-ca. 1607) una serie de obras en la exposición que comisarió en 1987 dedicada a "Los Ribalta y la pintura valenciana de su tiempo", la saga de pintores locales a la que perteneció este artífice comenzó a interesar a quienes iban añadiendo a este primer corpus documental y pictórico nuevas refe-

${ }^{1}$ Benito Doménech, F., Los Ribalta y la pintura valenciana de su tiempo, Catálogo, Madrid, 1987, pp. 65-83. 


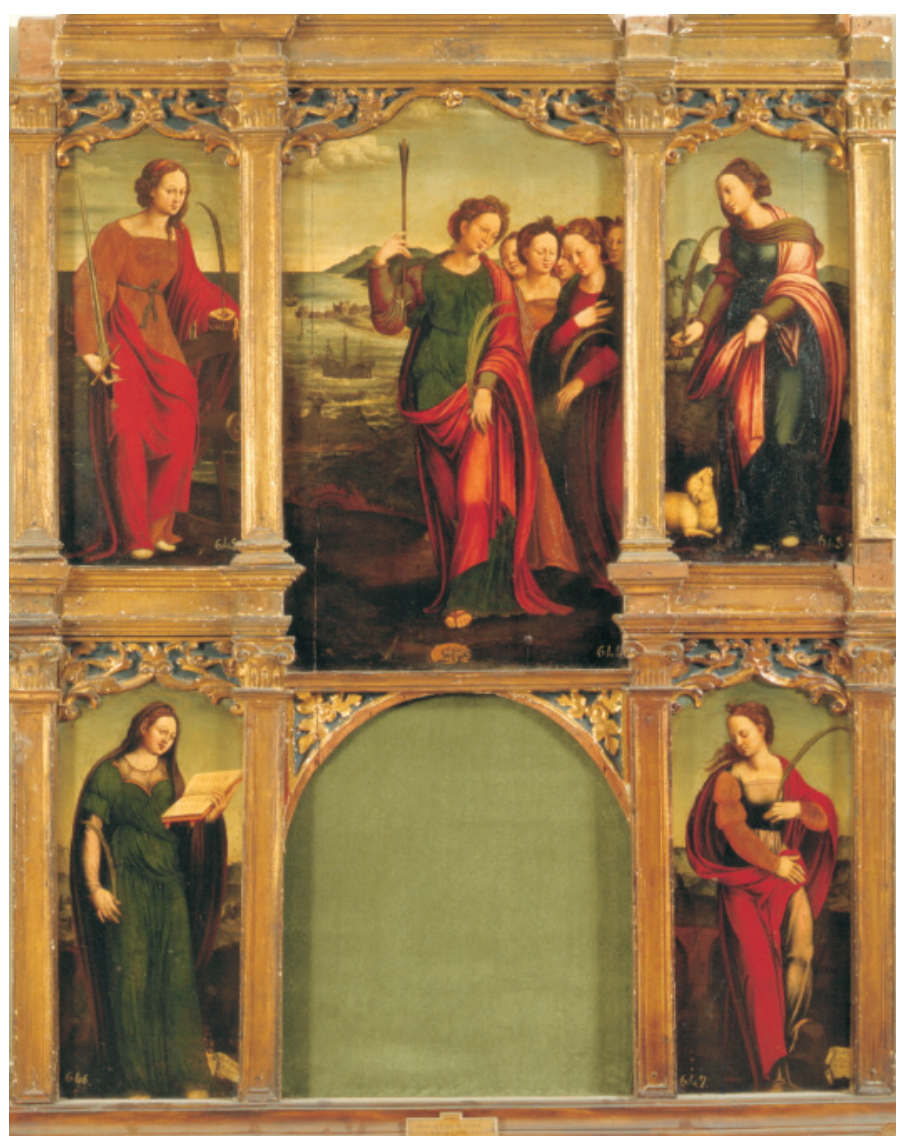

Fig. 1. "Retablo de Santa Úrsula y las vírgenes" (1540). Museo de Bellas Artes de Valencia.

rencias u obras que enriquecían sobremanera este desconocido taller familiar (activo, al menos, una centuria ${ }^{2}$ ).

Cabe indicar, sin embargo, que hasta ese momento la figura más conocida había sido la de Gaspar Requena el Viejo - oriundo de Cocentaina y activo en la primera mitad del s. XVI- gracias al retablo de "Santa Úrsula y las vírgenes" (Museo de Bellas Artes de Valencia) (fig. 1) que, junto a Pedro Rubiales, ejecutó para el convento de la Puridad de Valencia a partir de $1540^{3}$.

Las más recientes aportaciones de Benito vinieron a completar, también, las que este autor había desgranado años atrás respecto a Gaspar Requena el Joven (ca. 1530-ca. 1603) ${ }^{4}$, hijo homónimo del Viejo, tío de Vicente el Joven y padre de Miguel y Jerónima Eugenia; y en menor medida de Vicente Requena el Viejo (ca. 1535-1590?), su segundo vástago, padre a su vez de su joven homónimo.

\footnotetext{
2 Como mínimo, tal como da cuenta la documentación conocida a día de hoy, entre 1531 y 1605.

3 CAmpos, C., "El retablo de Santa Úrsula o de las vírgenes del Convento de la Puridad de Valencia", Anales de la Universidad de Valencia, XI, 83, 1930-31, pp. 200-201.

${ }^{4}$ Benito Doménech, F., Pinturas y Pintores en el Real Colegio de Corpus Christi, Valencia, 1980, pp. 120-124.
} 
Esta sucinta relación nos sirve para poner de relieve la huella que este enigmático taller dejó en la pintura valenciana entre los inicios del s. XVI y los primeros años del s. XVII ${ }^{5}$. Pero, sobre todo, para poder reivindicar el papel que pudo jugar en el panorama pictórico contemporáneo Gaspar Requena el Joven y, tal vez, sus hijos naturales (Miguel y J. Eugenia) y políticos (Pedro Mateo) en un amplio conjunto de obras que -adjudicadas por F. Benito a un incierto "Discípulo joanesco de Montesa" (inaugurada en Xàtiva el 2 de abril de 2007), han sido relacionadas por González Baldoví con el primero de ellos; siendo sin duda susceptibles de ampliarse en un futuro no lejano a la luz de las concomitancias. Pinturas que forman un sólido corpus que nos ayuda a calibrar mejor las deudas y contribuciones del linaje de los Requena en un período clave de la pintura valenciana del Renacimiento, y que abarca desde la irrupción de los Hernandos hasta la de Francisco Ribalta. Un buen ejemplo de cómo ejercieron su oficio ininterrumpidamente los integrantes de un taller (o, quizás, dos) al socaire de la potencia artística de los pintores citados, de sus discípulos, seguidores o coetáneos y, sobre todo, de los Macip de la mano de Joan de Joanes (ca. 1505/10Bocairent, 1579).

\section{Gaspar Requena el Viejo (Cocentaina, finales del s. XV-segundo tercio del s. XVI)}

Confundido con su hijo homónimo, desde Orellana se creyó erróneamente que su trayectoria artística abarcaba un fecundo período entre 1531 y $1603^{8}$, como oportunamente advirtió Benito Doménech ${ }^{9}$. La obra que define su quehacer, contratada con Pedro Rubiales en abril de 1540, es el retablo de "Santa Úrsula y las vírgenes" para el convento capitalino de la Puridad, como se ha dicho. Conjunto con el que se ha relacionado recientemente una tabla con las "Lamentaciones a la muerte de Cristo" que custodia la parroquial de Nuestra Señora de la Asunción de Foios ${ }^{10}$, en

\footnotetext{
5 Véase la Tabla I con las pinturas atribuidas a los Requena, donde aparecen únicamente aquellas obras de las que podemos elucubrar una cronología aproximada. Otras pinturas adscritas a esta fecunda familia de artífices (especialmente a Vicente Requena el Joven) pueden consultarse en las obras de Fernando Benito antes citadas.

${ }^{6}$ No cabe duda que bajo este pseudónimo se esconden varias manos creadoras. En otras palabras, con esta nomenclatura convencional se halla en realidad el quehacer de un activo taller (diversas manos y, consiguientemente, calidades) encabezado con probabilidad por Gaspar el Viejo, Gaspar el Joven y Vicente el Viejo sucesiva o paralelamente y con diversas fases en su desarrollo a lo largo del s. XVI. Obrador en el que pudieron en buena lid formarse y participar puntualmente Jerónima Eugenia, Miguel, Vicente el Joven (antes de 1585) y Pedro Mateo.

7 GonzÁlez Baldoví, M., “Artistas y clientes en Xàtiva, 1550-1707”, La Llum de les Imatges: Lux Mundi (Xàtiva 2007). Libro de estudios, cap. XXII, Salamanca, 2007, pp. 545-547. Lamentablemente, Boluda Perucho, A., "Libro de la cofradía del Santísimo Sacramento de la Colegiata de Xàtiva", La Llum de les Imatges: Lux Mundi (Xàtiva 2007). Catálogo, Salamanca, 2007, p. 851, confunde la paternidad de Gaspar Requena el Joven, al referir: "El miniaturista era un pintor bastante conocido, natural de Cocentaina y afincado en Valencia, padre del pintor Vicent Requena".

${ }^{8}$ Orellana, M. A., de Biografía pictórica valentina; ed. de Xavier De Salas, Valencia, 1967, p. 72; Alcahalí, Barón DE, Diccionario biográfico de artistas valencianos, Valencia, 1897, pp. 254-255; SAnchís Sivera, J., Pintores medievales en Valencia, 1930, p. 238; Campos, C., Art. cit., pp. 187-202; Tormo, E., Valencia. Los Museos, Madrid, 1932, pp. 62 y 165; Post, R. Ch., A History of Spanish Painting, Cambridge, XI, 1953, pp. 85-105; Angulo, D., Pintura del Renacimiento, “Ars Hispaniae”, vol. XII, Madrid, 1954, pp. 174-177; Garín, F. M., Catálogo Guía del Museo Provincial de Bellas Artes de San Carlos, Valencia, 1955, p. 167 y Aldana Fernández, S., Guía artística de la Real Basílica de Nuestra Señora de los Desamparados, Valencia, 1971, p. 42.

9 Benito DomÉnech, F., op. cit., 1980, p. 120.

${ }^{10}$ Ferrer OrTs, A., "Un temple singular a l'Horta Nord: l'església de l'Assumpció de Nostra Senyora (Foios)", La Roda del Temps, 11, 2002, pp. 42-43.
} 
base a sus claras concomitancias formales con la misma escena. Quizás también fue el autor del retablo de la "Virgen de las Virtudes", en 1556, para la iglesia de San Esteban de Valencia". Oriundo quizás de Cocentaina, fue padre de Gaspar Requena el Joven y de Vicente Requena el Viejo, nacidos probablemente entre 1530 y 1535 , y también pintores.

\section{Gaspar Requena el Joven (Cocentaina, ca. 1530-ca. 1603)}

Según Alcahalí casó en 1555 con Úrsula Feliu, con quien tuvo cinco hijos entre 1556 y 1565; dato que coincide con la parentela de su hermano Vicente y del que dio buena cuenta Benito en su día ${ }^{12}$. Recientes aportaciones de González Baldoví lo sitúan en la ciudad de Xàtiva, donde (casado con Isabel Joan) bautizó en 1559 a una niña con el mismo nombre materno y en 1562 a Ana Dorotea ${ }^{13}$, aunque ya en la capital del reino se da cuenta de una tercera hija, Jerónima Eugenia ${ }^{14}$, donde, probablemente viudo, pudo contraer segundas nupcias con Eufemia Zapata ${ }^{15}$.

A partir del comienzo de 1568 aparece tasando unas obras de su colega Luis Mata, desde 1569 trabajando para el Patriarca (cuyos trabajos “(...) son, en su mayor parte, ajenos al Colegio de Corpus Christi, que aún estaba por construir, y se centran casi todos en la villa de recreo que el prelado tenía en el camino de Alboraya (...) Generalmente son trabajos menores (...)"16 y, más tarde (1575), colaborando en el dorado del artesonado de la Sala Grande del entresuelo del palacio de la Generalitat ${ }^{17}$. Un año después contrataba la ejecución de un retablo para la familia Sapena en el convento de Santo Domingo de la ciudad del Turia, en 1580 actúa de tasador de un retrato de "Jaime I" realizado entonces por Sariñena para la citada institución local (año en el que la viuda de Joan de Joanes y sus hijos le otorgan escritura de procura ante Cristóbal Llorens), así como el dorado del artesonado de la Sala Pequeña del mismo palacio (1583). Mientras que los últimos servicios los presta a Bartolomé Matarana, en 1602, en labores de dorado del retablo mayor del templo de Corpus Christi ${ }^{18}$.

${ }^{11}$ Cerveró Gomis, L., Pintores valentinos, su cronología y documentación, Separata de Anales del Centro de Cultura Valenciana, Valencia, 1964, p. 106.

12 Benito Doménech, F., op. cit., 1980, p. 120. No hace mucho, la profesora Gómez Ferrer Lozano, M., Arquitectura en la Valencia del siglo XVI. El Hospital General y sus artífices, Valencia, 1998, p. 350, equivoca el parentesco entre nuestro protagonista y Vicente Requena el Viejo, a quien confunde como su padre cuando en realidad fue su hermano. En el haber de esta investigadora está el hecho de haber aportado datos de archivo de primera mano acerca de su obra, como sus trabajos en el Hospital General de Valencia y en el retablo mayor del Convento de Corpus Christi de Llutxent.

13 GonZÁlez Baldoví, M., op. cit., p. 545.

14 Benito Doménech, F., op. cit., 1980, p. 120.

15 Ibidem.

${ }^{16}$ Benito Doménech, F., op. cit., 1980, p. 121. El 20 de mayo de 1568 tasa, junto a Joanes, una pintura de Luis Mata para el reloj del Estudi General de la capital del reino.

${ }_{17}$ Cabe indicar que, con anterioridad a este trabajo, en la Visita Pastoral realizada en 1574 a la ermita de San Sebastián de Vallada se relata el siguiente tenor por Miguel de Espinosa, estrecho colaborador del Patriarca (patrón a su vez de algunos Requena, como se sabe): "Otrosí quel honrrado Gracián Alcover menor de días, a cuyo cargo está la ermita de Sant Sebastián, que de aquí a San Juan haga traer el retablo [tal vez el dedicado a "San Sebastián, San Fabián y San Roque" hoy desmembrado y, en parte, desaparecido que atribuimos a los Requena] de Valencia (...)". Informaciones recogidas de Garrido, H.-Pelejero, J. A., Vallada, su evolución urbana entre los siglos XIII al XIX, Vallada, 2000, pp. 99-100. Lo que, de ser verosímil, indicaría que Gaspar Requena el Joven y su taller se ubicaban en Valencia, desde donde atendían a su clientela de las comarcas centrales del reino de Valencia.

18 Benito DomÉnech, F., op. cit., 1980, pp. 121-122, basándose en informaciones de Boronat. 
La carencia de obra segura debida a su mano ha venido a situar a nuestro protagonista hasta ahora como un pintor ciertamente oscuro y de carácter secundario que, dedicado a tareas más mecánicas que creativas, transitó por tierras valencianas (probablemente al lado de su hijo Miguel, con quién se le documenta) durante la segunda mitad de la centuria. El hecho de que González Baldoví, como arriba hemos apuntado, haya relacionado el estilo de Gaspar con una miniatura conservada en el Llibre de la Luminaria del Santíssim Sacrament que comença l'any 1561 i acaba en 1644 (Archivo Histórico de la Colegiata de Xàtiva) -concretamente por "(...) dos àngels ab un veser e un sant crucifici" por la que recibió 6 sueldos en 1561- (fig. 2) ha posibilitado, probablemente con escaso margen de error, que atendiendo a la similitud manifiesta de estilo entre esta obra y las creaciones adscritas al "Discípulo joanesco de Montesa", actualmente podamos argumentar que dicha producción haya que asociarla a nuestro artífice y su complejo taller ${ }^{19}$. Además de otras obras que ahora presentamos y que se han expuesto en su mayoría en las muestras que la Generalitat Valenciana ha realizado últimamente (a través de la Fundación de la Comunidad Valenciana La Luz de las Imágenes) en Alicante y Xàtiva ${ }^{20}$.

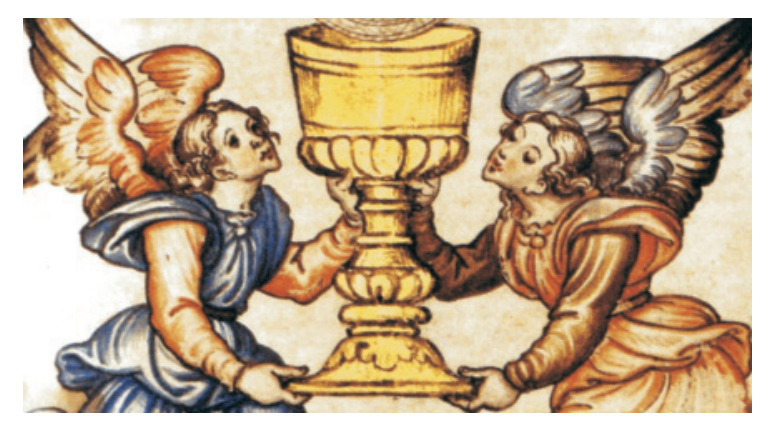

Fig. 2. Miniatura (1561). Archivo Histórico de la Colegiata de Xàtiva.

Así pues, tanto el retablo de "San Sebastián, San Fabián y San Roque" (1559) de Montesa (figs. 3 y 4), que inspiró a Benito para bautizar a su autor como discípulo de Joanes ${ }^{21}$, como el homónimo de Vallada (ca. 1574)22 (fig. 5); las tablas dedicadas a los "Pasajes de la vida de Santo Domingo" (figs. 6, 7, 8 y 9) que, depositadas en el Museo de Bellas Artes de Valencia, son originarias del convento dominico de Sant Onofre de la capital de la Costera ${ }^{23}$; las tablas

\footnotetext{
19 GonZÁlez BAldoví, M., op. cit., pp. 545-546. La evidente relación de esta miniatura con el modus operandi del incierto "Maestro joanesco de Montesa", apelativo con que Benito Doménech, F., Joan de Joanes. Una nueva visión del artista y su obra. Catálogo, Valencia, 2000, p. 39, bautizó al artífice de diversas obras que se hallaban interconectadas con el retablo de "San Sebastián, San Fabián y San Roque" (1559) de la parroquia de Nuestra Señora de la Asunción de Montesa, no invita -sin embargo- a una adscripción tan sencilla. La asociación de numerosas obras al quehacer de Gaspar Requena el Joven incita seriamente a la reflexión, como se verá en la conclusión de este trabajo.

20 "La Faz de la Eternidad" (Alicante) y "Lux Mundi" (Xàtiva).

21 Ferrer Orts, A.-Aguilar Díaz, C., "Retablo de San Sebastián”, La Llum de les Imatges: Lux Mundi (Xàtiva 2007). Catálogo, Salamanca, 2007, pp. 554-557.

22 Garrido, H.-Pelejero, J. A., op. cit., pp. 99-100 y Aguilar Díaz, C. "Santa Catalina de Siena”, La Llum de les Imatges: Lux Mundi (Xàtiva 2007).Catálogo, Salamanca, 2007, pp. 546-547 y Aguilar Díaz, C., "Flagelación de Cristo", op. cit., pp. 548-549.

${ }^{23}$ Aguilar Díaz, C.-Ferrer Orts, A., “Aparición de la Virgen a Santo Domingo entregándole el hábito; Santo Domingo entre San Pedro y San Pablo; Aprobación por Honorio III de la orden dominica y Ordalía en Fanjeaux", op. cit., pp. 558-561.
} 


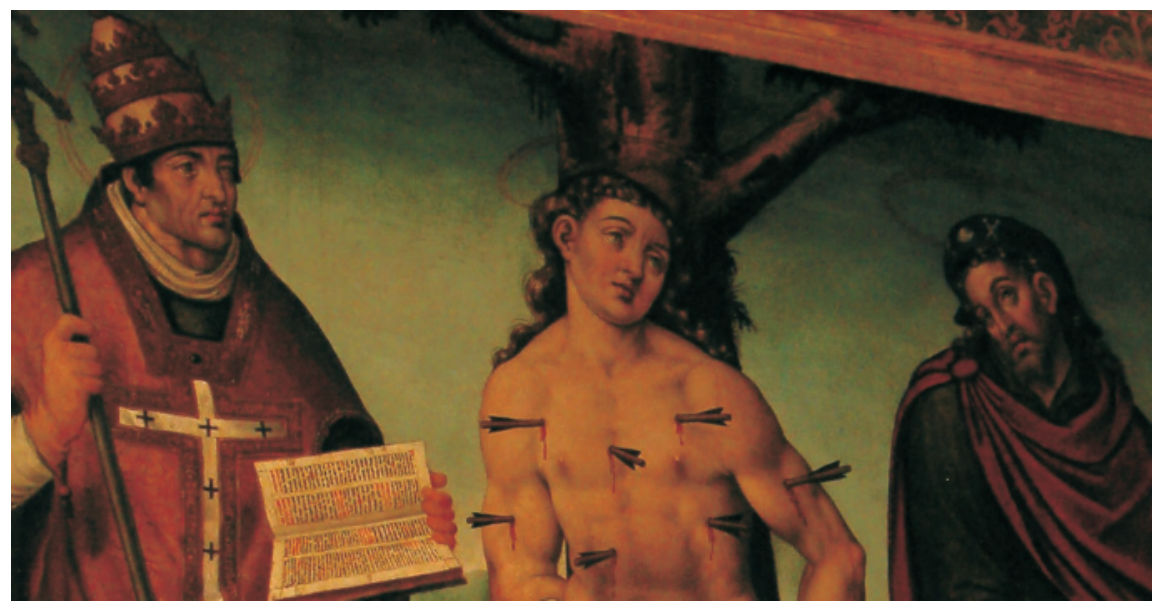

Fig. 3. Retablo de San Sebastián, San Fabián y San Roque (detalle), 1559. Iglesia parroquial de Montesa.

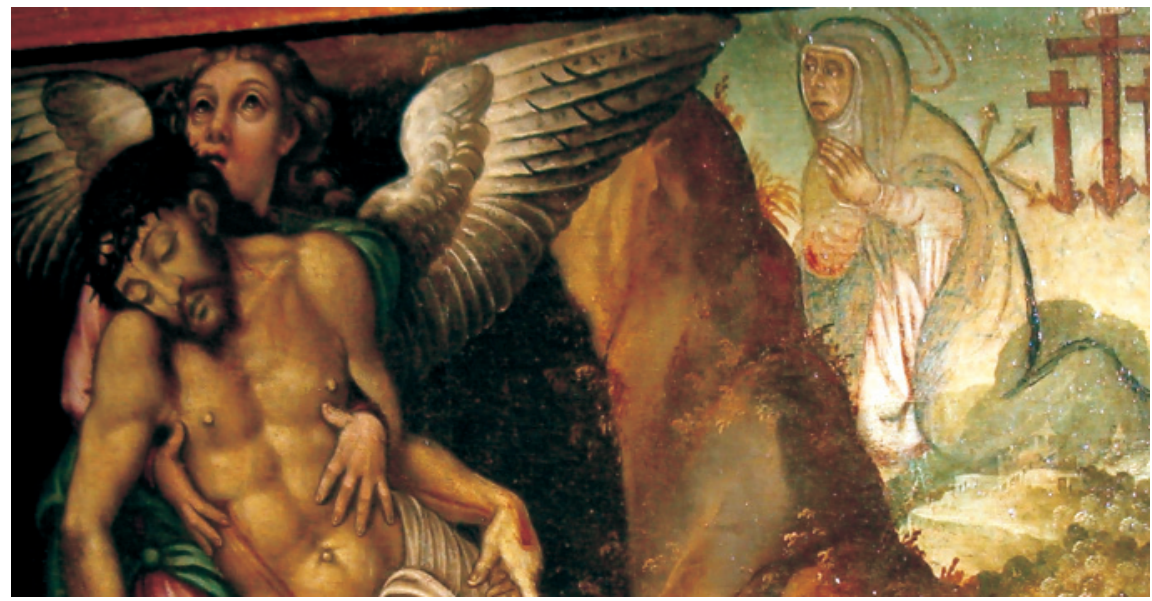

Fig. 4. Retablo de San Sebastián, San Fabián y San Roque (detalle), 1559. Iglesia parroquial de Montesa.

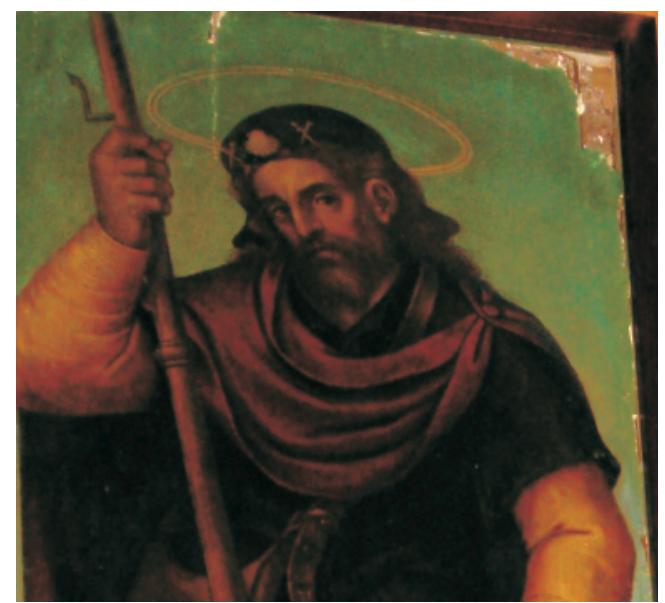

Fig. 5. "San Roque" (detalle), ca. 1574. Iglesia parroquial de Vallada. 


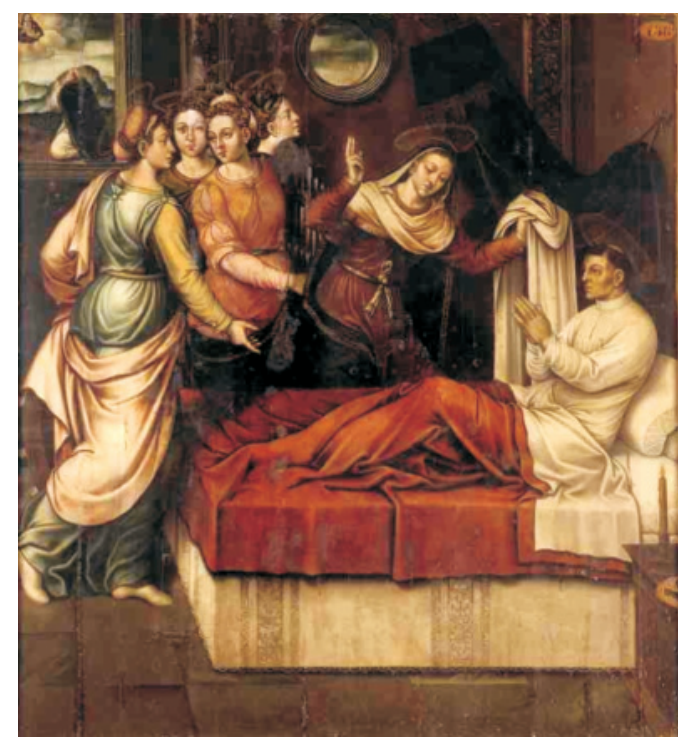

Fig. 6. “Aparición de la Virgen a Santo Domingo entregándole el hábito" (ca. 1535-40). Museo de Bellas Artes de Valencia.

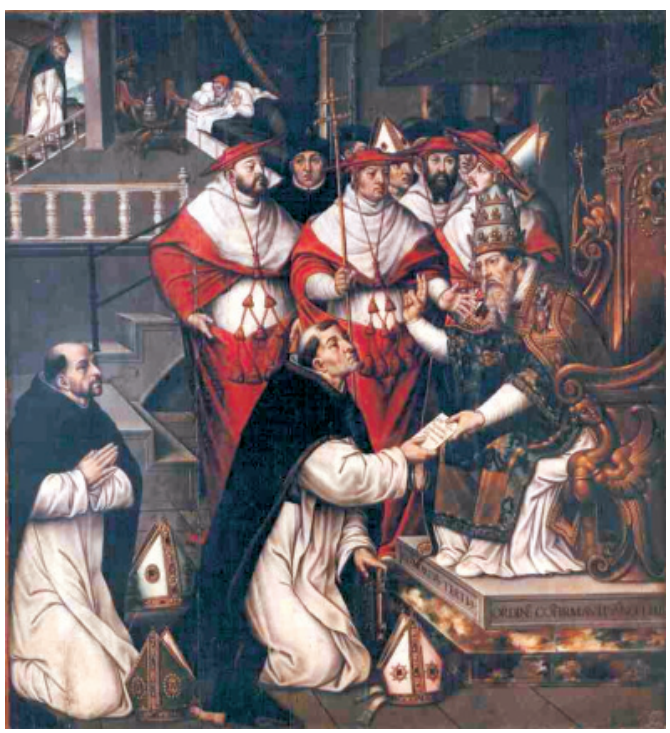

Fig. 7. "Aprobación por Honorio III de la orden dominica" (ca. 1535-40). Museo de Bellas Artes de Valencia.

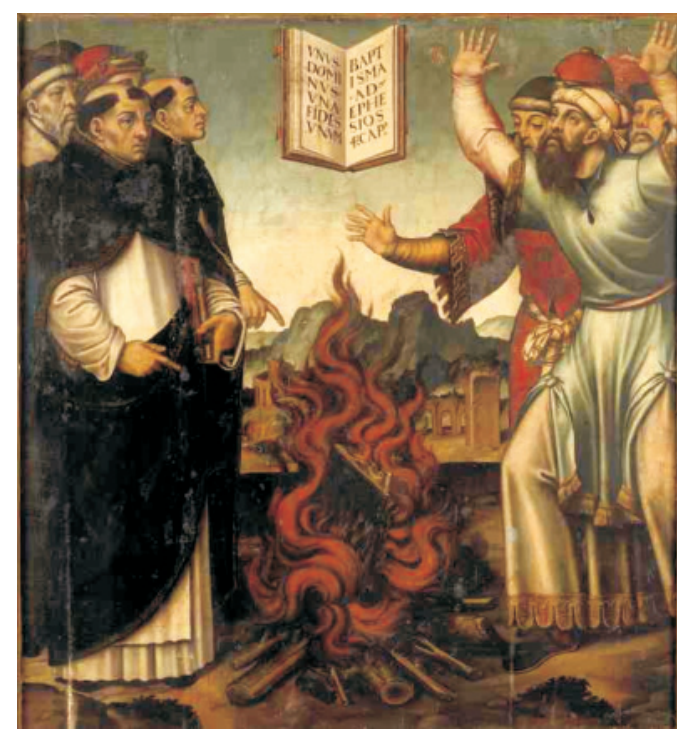

Fig. 8. "Ordalía en Fanjeaux" (ca. 1535-40). Museo de Bellas Artes de Valencia.

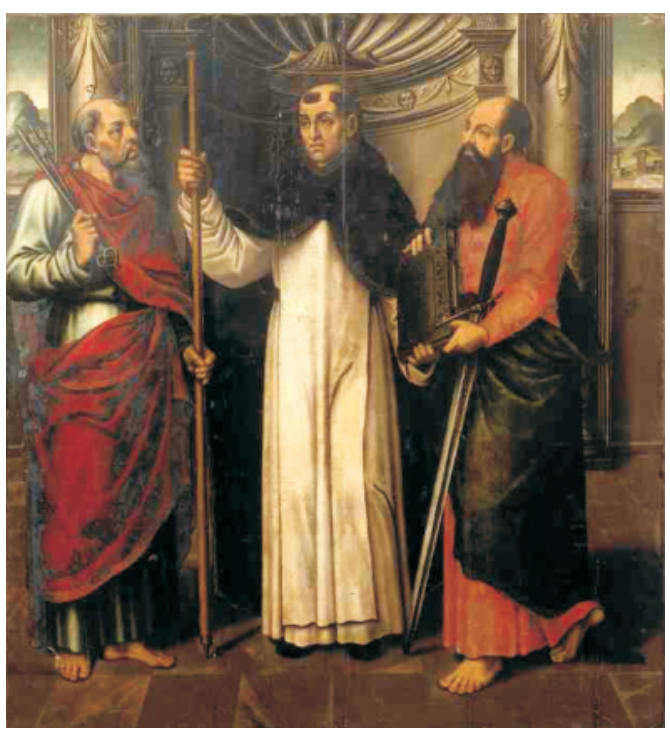

Fig. 9. "Santo Domingo entre San Pedro y San Pablo" (ca. 1535-40). Museo de Bellas Artes de Valencia. 


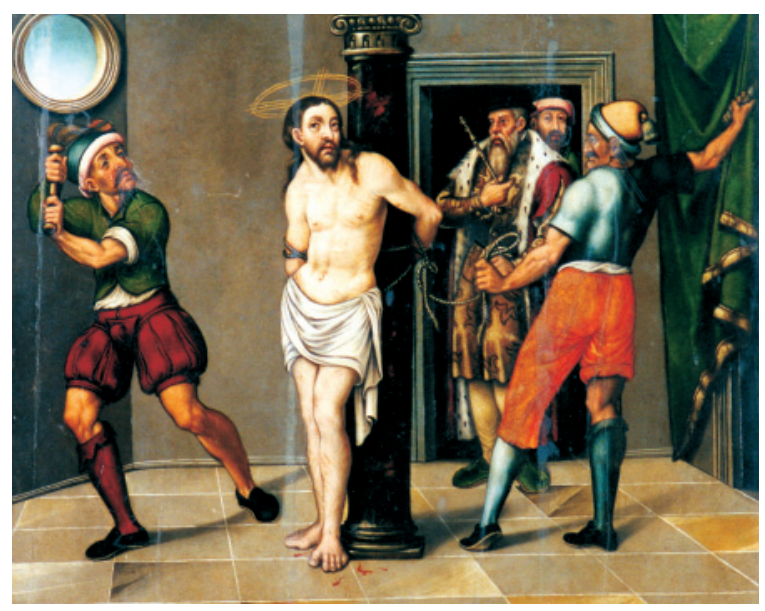

Fig. 10. "Flagelación de Cristo" (ca. 1560-70). Museo de l'Almodí (Xàtiva).

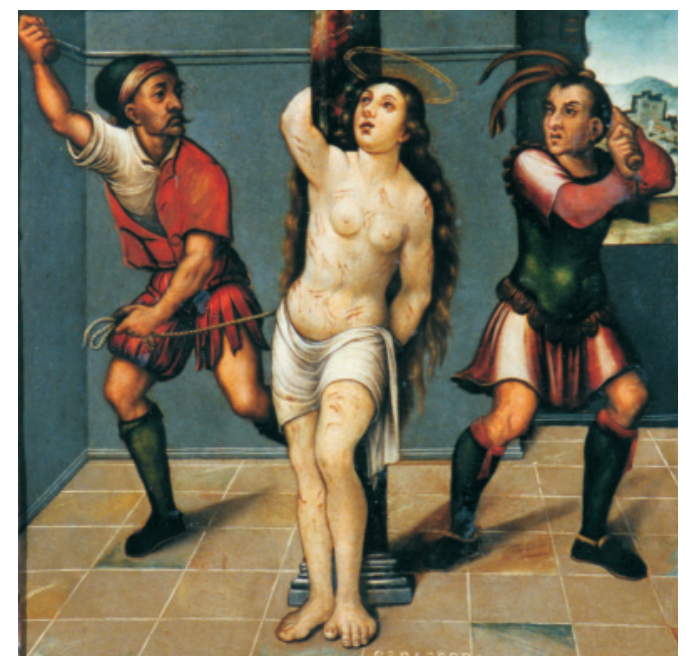

Fig. 11. "Flagelación de Santa Bárbara" (ca. 1560-70). Museo de l'Almodí (Xàtiva).

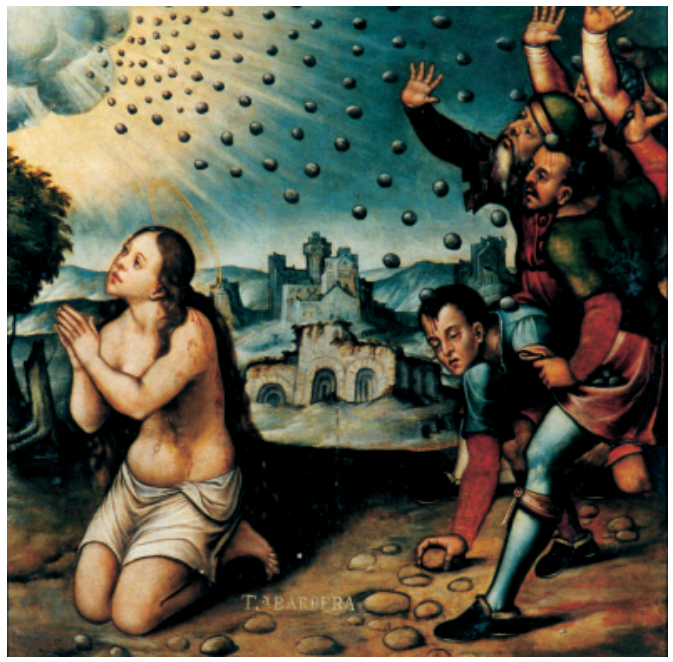

Fig. 12. "Lapidación de Santa Bárbara" (ca. 1560-70). Museo de l'Almodí (Xàtiva).

que provenientes del eremitorio de San José y Santa Bárbara se conservan entre los Museos de la Colegiata y de l'Almodí setabenses ${ }^{24}$ (figs. 10, 11 y 12); el retablo de "Santiago Apóstol" de la parroquial de Bocairent ${ }^{25}$ (figs. 13 y 14), las puertas bifaces de altar con un "Ecce Homo" y "Cristo a la columna" por un lado y los profetas "Ezequiel", "David", "Isaías" y "Jeremías"

\footnotetext{
${ }^{24}$ Ferrer Orts, A., "Sants Esposoris, Visitació, Fugida a Egipte, Oració de l’Hort, Flagel·lació de Crist, Flagel·lació de santa Bárbara, Martiri de santa Bárbara”, op. cit., pp. 550-553.

25 Benito Doménech, F., op. cit., 2000, p. 39.
} 


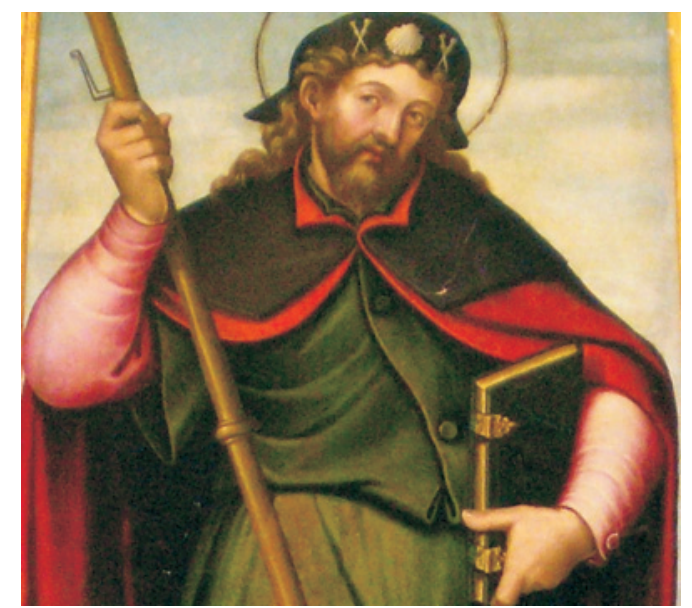

Fig. 13. Retablo de Santiago (detalle), ca. 1575-85. Museo parroquial de Bocairent.

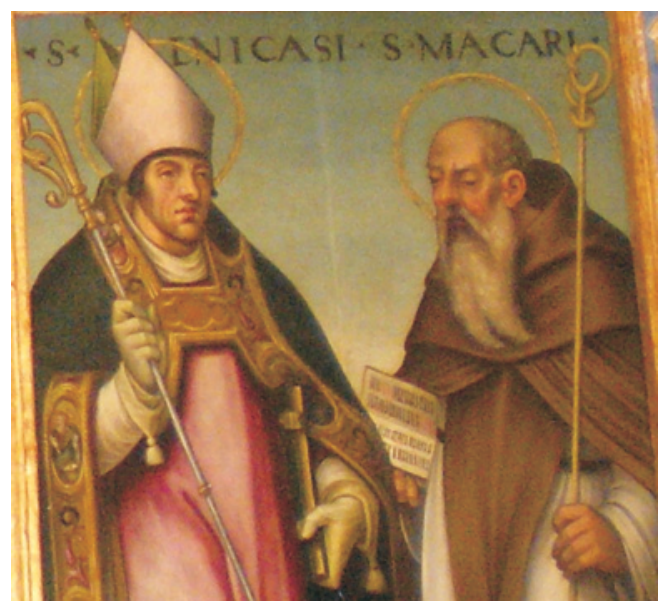

Fig. 14. Retablo de Santiago (detalle), 1575-85. Museo parroquial de Bocairent.

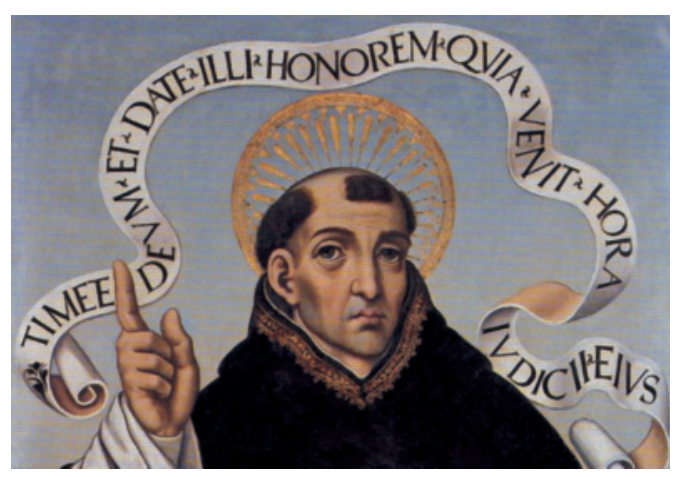

Fig. 15. "San Vicente Ferrer" (detalle), ca. 1600. Ermita de San Vicente Ferrer de Teulada.

por otro (Colección particular) ${ }^{26}$; el "San Vicente Ferrer" de la ermita homónima de Teulada ${ }^{27}$ (fig. 15), un "San Joaquín" del Calvario alto de Xàtiva ${ }^{28}$ y, probablemente, el retablo de almas del templo de Agullent ${ }^{29}$ (figs. 16, 17, 18 y 19) habrá que relacionarlas con el obrador de Gaspar, Miguel y Pedro Mateu (yerno del primero y cuñado del segundo, al estar casado con Jerónima

${ }^{26}$ Ibidem.

${ }^{27}$ López Azorín, M. J., "San Vicente Ferrer”, La Luz de las Imágenes. La Faz de la Eternidad (Alicante, 2006). Catálogo, Salamanca, 2006, pp. 244-245.

28 Tormo, E., Las tablas de las iglesias de Játiva, Madrid, 1912, p. 59 da cuenta de esta pintura junto a otras de un mismo retablo; sin embargo el cliché lo da a conocer más tarde MarTínez Aloy, J., Provincia de Valencia, vol. II de la Geografia General del Reino de Valencia, Barcelona, 1922, p. 472.

29 Ferrer Orts, A.-Aguilar Díaz, C., "Retablo de San Sebastián”, op. cit., 2007, p. 556. 

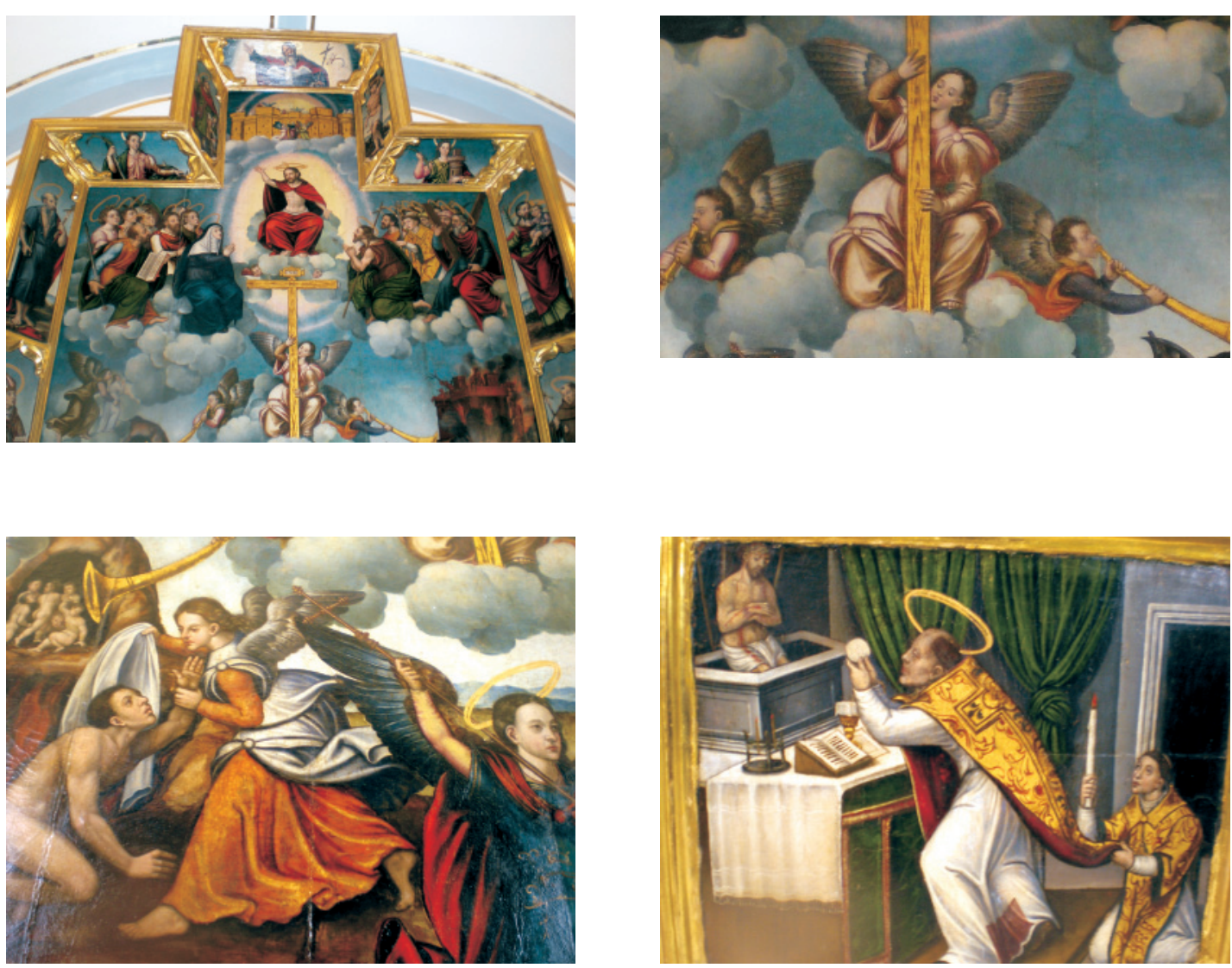

Figs. 16, 17, 18 y 19. Retablo de almas (detalles), ca. 1575-85. Iglesia parroquial de Agullent.

Eugenia, también pintora ${ }^{30}$, como veremos), sin descartar en absoluto la activa participación de Vicente y su hijo homónimo ${ }^{31}$.

\section{Pedro Mateo (ca. 1550-Valencia? 1604)}

Pintor que a finales de 1573 se desposó con Jerónima Eugenia Requena, hija ¿primogénita? de Gaspar Requena el Joven, a quien D. Juan de Ribera había dado una dote en septiembre de ese año. En 1577 actuó como testigo en la boda de Pere Bertomeu y tres años después su nombre

30 Benito Doménech, F., op. cit., 1980, p. 92 y Company, X., La Pintura del Renaixement, València, 1987, pp. 92-93.

31 CompanY, X., op. cit., p. 93, refiere agudamente al respecto: “(...) a manca de dades documentals concretes, no hauriem de fer massa càbales per considerar la més que probable col-laboració entre Gaspar Requena 'el Jove'i el seu germà Vicent Requena 'el Vell', car, a bon segur, tots dos treballarien en un mateix taller. Fins i tot podriem suposar, amb bastant de lòica també, que els foscos Miquel Requena, Jerónima Eugenia Requena i el seu marit Pere Mateu, formarien part del mateix taller, bé que en possible qualitat de colllaboradors secundaris". 
figura en los Quinque Libri de la parroquial de San Esteban de Valencia, lo que se sospecha pudo haber sido consecuencia del bautismo de un hijo de su matrimonio o la lógica consecuencia del apadrinamiento de una criatura ajena ${ }^{32}$.

En 1583, junto al pintor Pedro Juan Tapia, tasó una obra de Luis Mata realizada para la Generalitat; actuando además como perito al lado de Tapia para justipreciar en nombre de Genis Linares la obra de talla que este último había ejecutado en la Sala Daurada del singular palacio ${ }^{33}$.

A las órdenes del Patriarca llevó a cabo algunas obras a partir de noviembre de 1589, como el dorado de un retablito de la Casa del Huerto del arzobispo y en colaboración con Matarana el 3 de julio de 1604. Mes en el que debió fallecer, pues Jerónima aparece como viuda (conocida como "Matheua"), se pondrá a la cabeza de su obrador y recibirá los pagos debidos ${ }^{34}$.

\section{Jerónima Eugenia Requena (ca. 1556-?)}

Tal vez nacida en Xàtiva como sus hermanas y, quizás también, su hermano Miguel, estuvo ligada sentimentalmente como se ha visto al pintor Pedro Mateu a lo largo de tres décadas. Lapso en el que todo parece indicar por la escueta, aunque significativa, documentación que el profesor Benito aportó en su día que formaron un activo binomio (desconocemos si precisaron de la ayuda de más colaboradores) en labores secundarias, la mayor de las veces, para el arzobispo Juan de Ribera ${ }^{35}$.

Una vez viuda continuó con sus labores de dorado (como el altar del Ángel Custodio a mediados de julio de 1604 en la capilla de Corpus Christi), actividad que continuó en noviembre de ese mismo año en otras capillas del templo colegial. El 18 de febrero de 1606 percibía cierta cantidad "(...) por dorar una guarnicion que lleva el cuadro de la cena del altar mayor [de Francisco Ribalta] (...)". Acción que repetiría en 6 de noviembre de dicho año respecto al cuadro del "Hermano Francisco del Niño Jesús", de Sarinyena ${ }^{36}$.

\section{Miguel Requena (ca. 1558-?)}

Únicamente aparece citado al lado de su padre (Gaspar Requena el Joven), aunque sin mencionar su nombre, “(...) y un mancebo (...)", el 19 de febrero y el 25 de mayo de 1574, a las órdenes de Juan de Ribera ${ }^{37}$.

32 Benito Doménech, F., op. cit., 1980, p. 91.

33 Ibidem.

34 Benito Doménech, F., op. cit., 1980, p. 92. El caso de que las viudas de los cabezas de taller se pongan al frente del negocio familiar no fue extraño ni en este período ni, por supuesto, en el medio valenciano. Véanse al respecto las Tachas Reales para comprobar como cada cinco años algunos eran los obradores que perdían a su maestro, por lo que sus respetivas esposas lo heredaban y gestionaban. En este caso, además, la hija de G. Requena el Joven responde como pintora que es a todos los efectos (compruébese esta circunstancia, por ejemplo, en FALOMIR FAUS, M., La pintura y los pintores en la Valencia del Renacimiento (1472-1620), Valencia, 1994, pp. 98-101). Cabe reseñar que la "Matheua pintora" de la que habla Rodrigo Pertegás, J., Historia de la Antigua y Real Cofradía de Nuestra Señora de los Inocentes Mártires y Desamparados, Valencia, 1922, p. 173 y recoge de éste Falomir (op. cit., p. 52) es J. Eugenia Requena.

35 Benito Doménech, F., op. cit., 1980, p. 92.

36 Ibidem.

37 Benito Doménech, F., op. cit., 1980, pp. 121 y 123. Para el santo prelado también consta que trabajaron el pintor Pedro Mateo y su esposa, e hija de Gaspar Requena el Joven (Benito Doménech, F., op. cit., 1980, pp. 122-123). 


\section{Vicente Requena el Viejo (Cocentaina, ca. 1535-1590?)}

El conocimiento que del pintor tenemos queda resumida en que en 1555 casó con Úrsula Feliu, matrimonio del que tuvo cinco hijos (de los que sólo conocemos los nombres del mayor, Vicente, y del menor, Francisco Juan), así como su colaboración en el retablo de "San Esteban" que, conjuntamente realizó con Joanes para la iglesia capitalina de la que el santo era titular hacia $1556^{38}$. Concretamente, así parece deducirse del estilo de las tablas de la "Ordenación de San Esteban", la "Oración del Huerto" y los "Improperios" (Museo del Prado), aunque recientes informaciones debidas al biógrafo seiscentista Vicente Vitoria utilizadas por Benito vienen a poner en relación las dos últimas tablas, sobre todo, con el pintor aún desconocido Onofre Falcó ${ }^{39}$; lo que dio pie en su día a adscribirle otras obras como la "Procesión al monte Gárgano" (Museo de Pau, Francia), la "Rebelión de los ángeles", la "Muerte de la Virgen" o una serie sobre "San Dionisio" (Museo de Bellas Artes de Valencia), entre otras ${ }^{40}$.

$\mathrm{Su}$ quehacer se singularizaba, pues, en el gusto por las “(...) esbeltas figuras de alargada anatomía con rostros graves, serenos, y un peculiar modo de fruncir telas mediante agudos pliegues rectilíneos que confieren a sus volúmenes un aspecto geométrico"41.

\section{Vicente Requena el Joven (Valencia, 1556-ca. 1607)}

Fue uno de los pintores más significativos que transitaron entre el romanismo joanesco y la pintura reformada de finales del siglo XVI. Si se quiere, en su obra se detectan las primeras influencias -y a su vez confluencias- entre la pintura escurialense y la autóctona (baste recordar que, el 15 de agosto de 1593, actuó como testigo en las pruebas de sangre de Juan Sánchez Coello, hermano del afamado pintor valenciano) $)^{42}$. Aunque, quizás, esta evolución estilística pudo deberse

\footnotetext{
38 Benito Doménech, F., “Vicente Requena 'el Viejo', colaborador de Joan de Joanes en las tablas de San Esteban del Museo del Prado”, Boletín del Museo del Prado, VII, 19 (enero-abril, 1986), pp. 13-29. Sin embargo, el mismo autor [atendiendo a las informaciones inéditas hasta el momento del biógrafo Vicente Vitoria en Academia de pintura del Señor Carlos Maratti, manuscrito conservado en la Biblioteca Corsini, Roma; analizado por BASSEGODA, B., "Vicente Vitoria (1650-1709), primer historiador de Joan de Joanes", Locus Amoenus, 1, 1995 pp. 165-172] matiza su primigenia opinión y adscribe al menos dos de las obras adjudicadas a Vicente Requena el Viejo a un todavía poco conocido Onofre Falcó. Véase al respecto Benito DomÉNECH, F., op. cit., 2000, pp. 148 y ss.

39 Pintor al que no se conoce actualmente obra alguna, aunque se sabe que tenía taller propio, paga la tacha en 1542 , 1547 y 1552 y es citado como pintor de la ciudad en 1552 (Falomir Faus, M., op. cit., pp. 99-101). Además, entre 1554-55 mantuvo una relación profesional con Joan de Joanes por la fabricación del banco del retablo de la parroquia valenciana de San Bartolomé. Más recientemente, GóMEZ-FerRer LozANo, M., op. cit., 1998, p. 344, señala que aparece localizado trabajando para el Hospital General de la capital del Turia entre 1539 y 1540, toda vez que discrepa con Falomir sobre la fecha en que fuera nombrado pintor del cap i casal y de la Diputación (1556) para sustituir a Juan Cardona, apoyándose en Alcahalí. Esta prolífica autora valenciana aporta un juicio interesante sobre su destreza profesional al referir que "Las noticias que tenemos no son por encargos de importancia sino más bien pintura ornamental, a excepción de las figuras en frontales y cortinas. No se tiene noticia de encargos de retablos, por lo que estaría dentro de la tradición de los pintores ornamentales o cofreneros".

40 Benito Doménech, F., op. cit., 1987, p. 66. Según Company, X., op. cit., p. 93, Vicente Requena el Viejo aparecería retratado en la "Ordenación de San Esteban".

41 Benito Doménech, F., op. cit., 1987, pp. 66-67.

${ }^{42}$ García Rey, C., "Nuevas noticias para la biografía del pintor Alonso Sánchez Coello", Boletín de la Sociedad Española de Excursiones, XXXV, 1927, p. 206. Lo que presupone, para BENITO DomÉNECH, F., op. cit., 1987, p. 68: “(...) una estancia anterior en la Corte (...) De ser ello cierto hallaría toda su explicación el influjo escurialense (...)”. Sobre este proceso y la familia de Alonso Sánchez Coello, pintor del rey Prudente, véase también Breuer-HermanN, S., "Alonso Sánchez Coello, vida y obra”, Alonso Sánchez Coello y el retrato en la Corte de Felipe II. Catálogo, Madrid, 1990, pp. 14-16. FALOMIR FAUS, M., op. cit., pp. 47-48 recuerda “(...) los múltiples contactos que existían entre la Corte y el medio pictórico valenciano (...) especialmente intensas con motivo de dos visitas regias a la ciudad [1599 y 1604]”.
} 
tanto a la asimilación del estilo paterno como a su relación con el pintor aragonés Juan Sariñena, poseedor de una técnica en la que es frecuente la pincelada sobria y abreviada que contribuye a realzar la severidad de sus formas.

No obstante, cabe reseñar que el Naturalismo en sí apenas les sedujo, como tampoco lo hicieron los primeros tonos claroscuristas del período, manteniéndose anclado en cierto academicismo a medio camino entre los logros escurialenses y la tradición joanesca ${ }^{43}$.

En su cada vez mejor conocida biografía artística, en la que ha tenido un destacado papel Fernando Benito, se evidencian dos grandes etapas. Mientras que en la primera se dejan entrever influencias paternas en el canon alargado de sus anatomías (aunque paulatinamente más proporcionadas), rostros graves y serenos y un acusado geometrismo de los pliegues de los mantos, también se vislumbra una gama cromática fría a base de blancos, celestes, malvas, carmines y amarillos, como el gusto por los paisajes montañosos abreviados y difuminados ${ }^{44}$. En la segunda se adivina un claro y, a la vez, sorprendente estancamiento de su pintura ${ }^{45}$.

Sus primeras obras se documentan en el monasterio jerónimo de San Miguel de los Reyes (Valencia) desde $1589^{46}$, tal vez debido a la mediación del también pintor fray Nicolás Borrás, de quien si no fue discípulo quizás si tuvo una estrecha relación. Pero también se le detecta en la ejecución de las pinturas de la Sala Nova de la Generalitat (concretamente en los retratos del Braç Eclesiàstic), realizadas “(...) siguiendo la pauta trazada por Sariñena (...)" en $1592^{47}$ y en el retablo de "San Silvestre" (1597), concertado con los jurados de la ciudad de Alzira ${ }^{48}$.

A partir de 1600 aproximadamente (coincidiendo con la llegada a la ciudad del Turia de Francisco Ribalta $\left.{ }^{49}\right)$ no detectamos apenas avances en su prometedora producción. Más bien al contrario,

43 Company, X., op. cit., València, p. 93, postula que "Per primera vegada (...), l'ortodòxia joanesca comença a qüestionar-se". Para Falomir Faus, M., op. cit., pp. 45-46: "La pintura valenciana del último tercio del siglo XVI está siendo objeto de una fecunda revisión (...) van perfilándose los contornos (...) de una realidad ya no circunscrita (...) a la omnímoda influencia de Joan de Joanes y sus epígonos. Junto a ella coexistió, y en algunos momentos en clara interconexión, otra corriente artística que bebía sus fuentes en el manierismo reformado, bien de procedencia romana (Juan Sariñena), bien escurialense (Vicente Requena el Joven o el primer Ribalta), pero en ambos casos inspirada en el ejemplo zuccaresco".

44 Para Benito Doménech, F., op. cit., 1987, p. 66, no cabe duda de que fue deudor del estilo de Vicente el Viejo, lo que podría explicar la relativa independencia hacia modelos joanescos. Según CoMPANY, X., op. cit., p. 94: “(...) Vicent Requena 'el Jove' (...) és molt probable que hagués intervingut en algunes de les obres que Benito atribueix al seu pare (...)". Sobre su estilo de técnica sumaria... de raíz sariñenesca como también inspirado, en un primer estadio, en la pintura escurialense de Diego de Urbina o Miguel Barroso, véase Benito DoménEch, F., op. cit., 1987, p. 67.

45 Benito Doménech, F., op. cit., 1987, p. 73. A pesar de su “(...) incontestable enfilament vers la nova aventura naturalista" (COMPANY, X., op. cit., p. 94).

46 Benito DomÉnech, F., op. cit., 1987, p. 67: “(...) la primera mención de Requena en Valencia aparece en 1587”. Este autor, sin embargo, cuestiona el grueso de las obras que en un principio había asociado a V. REQUENA el Joven en "Miguel Joan Porta. Nuevas obras", Ars Longa, 5, 1995, pp. 133-138. También puede consultarse la magnífica monografía de Arciniega García, L., El monasterio de San Miguel de los Reyes, 2 vols. (vol. I, pp. 28, 79 y 158; vol. II, p. 115), Valencia, 2001, donde corrobora informaciones precedentes y añade datos de archivo.

${ }^{47}$ Martínez Aloy, J., La casa de la Diputación, Valencia, 1909-10, p. 158 y Benito Doménech, F., op. cit., 1987, p. 68. También puede verse la aportación de Aldana Fernández, S., "Pintura y pintores del Renacimiento en el Palau de la Generalitat Valenciana: símbolo y realidad", De Pintura valenciana (1400-1600). Estudios y documentación, Alicante, 2006, pp. 296-297.

48 Montagud Piera, B., "Noticia del retaule de Sant Silvestre de Vicente Requena de Alzira", Archivo de Arte Valenciano, 1981, pp. 56-57 y BENITo DomÉNECH, F., op. cit., 1987, pp. 68-69, quien relaciona su "intencionalidad naturalista" en las facciones del santo pontífice inspiradas en las del "Calixto III" pintado sobre guadamacil por Joanes, a partir de 1568, para la catedral de Valencia; además de reseñar sus deudas para con Coello, Urbina y Carvajal.

49 Pintor con quien a buen seguro coincidió en el templo parroquial de San Jaime de Algemesí pues, mientras Ribalta realizaba el retablo mayor dedicado al titular (firmado en 1603) y los correspondientes a "San José" y "San Vicente" (entre 1605-10), Vicente Requena el Joven pudo ejecutar el hoy disperso retablo dedicado a "San Joaquín y Santa Ana". 
pues Requena se instaló en creaciones más simples, de escenas inertes lejanas a los estilemas ribaltianos, tan proclives a los claroscuros y a las tonalidades cálidas ${ }^{50}$.

La historiografía reciente sospecha que el hecho de no hallarse entre los integrantes del Colegio de Pintores nacido en la capital del reino en 1607 puede deberse a su óbito, pues no se entiende cómo un artífice de su prestigio no hubiera formado parte de dicha asociación ${ }^{51}$.

\section{Conclusión}

No cabe duda que tras este enigmático "Discípulo joanesco de Montesa" bautizado por Benito Doménech; identificado en fechas recientes por González Baldoví con Gaspar Requena el Joven, como se ha señalado, no se esconde un único pintor. Es cierto que este artífice, cuya trayectoria vital parece circunscribirse fundamentalmente a los antiguos territorios de la Sotsgovernació de Xàtiva y a la capital del reino, queda aún necesitado de un acercamiento más fundamentado del que ahora presentamos; pero no lo es menos que quizás hayamos contribuido modestamente a enfocar de manera razonable que tras su figura se entrevé -sin duda- el quehacer de otros miembros de taller (muy posiblemente sus parientes más cercanos que, en diversas etapas, participaron activamente en numerosas obras). No es, pues, de extrañar que en algunas de las piezas que hemos reunido en esta ocasión se vislumbren, al menos eso creemos, las manos de Gaspar Requena el Viejo y Vicente Requena el Viejo (pinturas del retablo dedicado a Santo Domingo, Museo de Bellas Artes de Valencia), Vicente Requena el Joven (retablos de Agullent, Bocairent y Vallada) $\mathrm{y}$, tal vez, de otros menos reputados pero no por ello merecedores de olvido.

A nuestro parecer tampoco habría que dejar de lado la pista de la relación mantenida en las décadas centrales del s. XVI, por lo que hasta ahora se sabe, entre Gaspar Requena el Joven y Onofre Borja (un notario que era señor de Miralbó y comendador de la obra de Montesa en Benassal ${ }^{52}$ ), a través de su hijo Cristòfol Borja. Pues resulta curioso que, entre los comitentes del retablo de San Esteban del templo homónimo de la ciudad de Valencia, figura Marco Antonio de Borja y Pallás ${ }^{53}$ (probable pariente del anterior); conjunto en el que quizás los Requena intervinieron

\footnotetext{
Del que se conservan dos tablas: "San Joaquín" y la "Virgen con el Niño" (BENITo DoMÉNECH, F., op. cit., 1987, p. 71). COMPANY, X., op. cit., p. 94 le atribuye a Requena en dicha iglesia un "San Pablo", quizás por error. Benito llega incluso a barajar la hipótesis de una posible colaboración "(...) en algunos conjuntos debidos al equipo ribaltiano" (op. cit., 1987, p. 66). Particularmente, en el retablo para el convento de Santa Catalina de Sena y, sobre todo, en los cuadros de "San Juan Bautista", "San Juan Evangelista", "San Pedro" y "San Pablo" de la comunidad religiosa del Hospital General de Valencia (op. cit., 1987, p. 72). En todo caso, recientemente Gomis CoRell, J. C., L'obra pictórica de Francesc Ribalta a Algemesí, Algemesí, 2006, no se refiere a esta hipotética coincidencia en sus numerosos datos de archivo.

50 Benito Doménech, F., op. cit., 1987, p. 73, se pregunta qué pudo sucederle a Vicente Requena el Joven, ¿acaso que recayera en Sariñena (forastero y ajeno a la tradición pictórica local) el título de Pintor de la Ciudad en 1595? No obstante, COMPANY, X., op. cit., p. 94, refiere: “(...) els darrers membres de la família dels Requena intensifiquen el 'tour de force' que a finals de segle s'havia produït entre els addictes al codi joanesc i els seus contraris, tot decantant-se la balança vers la nova avantguarda de Joan Sarinyena". Afirmación que, como mínimo, habrá que matizar en términos absolutos a la luz de las nuevas atribuciones, como veremos. Aunque, en términos relativos, continúa siendo válida la aseveración de que Vicente Requena el Joven “(...) es artista de gran interés no sólo por encarnar el eslabón intermedio entre el romanismo joanesco y la pintura reformada que en el último tercio del siglo XVI implantó en Valencia Juan Sariñena, sino porque además supone la más temprana conexión entre la pintura escurialense y el medio valenciano" (BENITO DomÉneCH, F., op. cit., 1987, p. 66).

51 Benito Doménech, F., op. cit., 1987, p. 72.

52 González Baldoví, M., op. cit., p. 545.

53 Gómez-Ferrer Lozano, M., "Nuevas noticias sobre el retablo de la vida de San Esteban de Joan de Joanes", Boletín del Museo del Prado, 34, 1995, p. 14; citado por Benito DomÉnech, F., op. cit., 2000, pp. 150-151.
} 
en la "Ordenación de San Esteban", tabla que guarda considerables similitudes formales con la "Aprobación por Honorio III de la orden dominica", como se ha indicado, toda vez que ambas beben de la tabla del desaparecido retablo de San Eloy de Joanes para el templo capitalino de Santa Catalina.

De estar en el camino adecuado esta aproximación a dicha saga de pintores que, sucesivamente, recibieron en su estilo las influencias artísticas de los obradores más reputados de su tiempo como los regentados por San Leocadio, los Hernandos o los Macip (especialmente de Joan de Joanes ${ }^{54}$ ), gracias a la lógica interrelación profesional que el taller facilitaba, nos permite poner en valor las contribuciones de este linaje al panorama pictórico valenciano y así poder calibrar con más tino si cabe el papel de sus celebrados colegas contemporáneos. La desaparición de algunos de sus miembros a lo largo del quinientos, la incorporación y la emancipación de otros [sin descartar, quizás, la participación puntual de otros colaboradores como tal vez Cristóbal Llorens (figs. 20 y 21)], además del trasiego entre ciudades en busca de clientela, son los rasgos que definirán la huella de esta familia en el ambiente artístico valenciano.
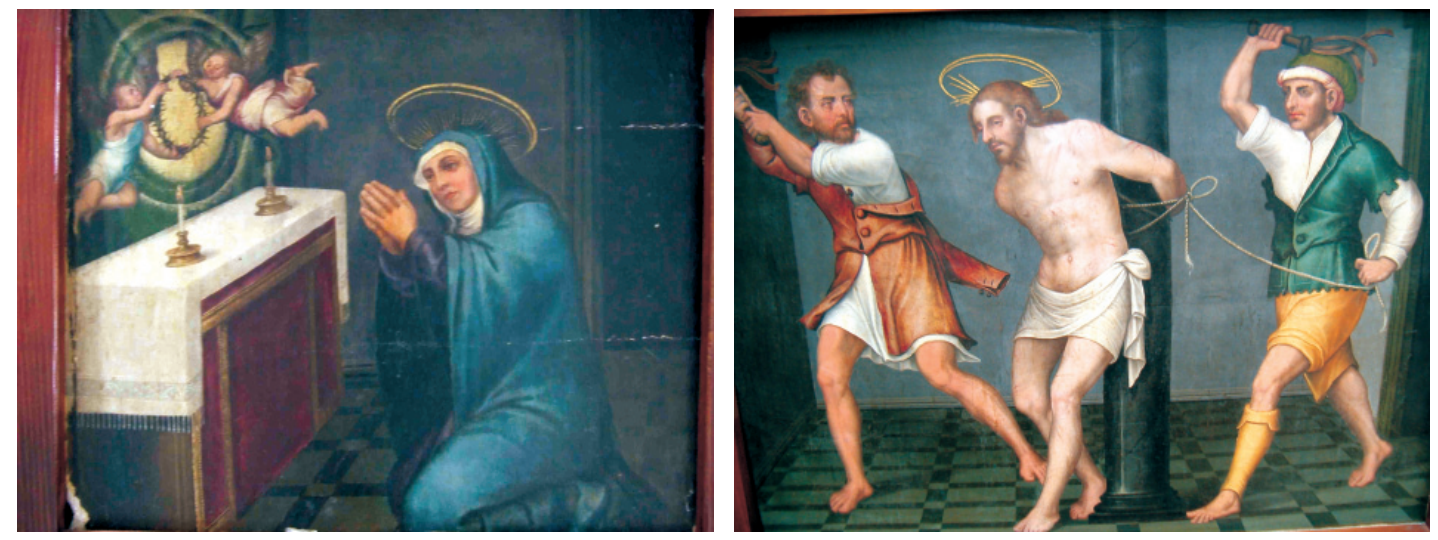

Figs. 20 y 21. "Santa Catalina de Siena” y "Flagelación de Cristo” (ca. 1570). Casa abadía (Vallada).

\footnotetext{
${ }^{54}$ Particularmente visible en el tratamiento de sus paisajes arruinados (inspirados en monumentos de la ciudad eterna) sazonados con tenues tonalidades entre azuladas y verdosas, composiciones, figuras y vestimentas. Llaman poderosamente la atención las semejanzas entre la "Coronación de San Eloy", del retablo homónimo de la parroquial de Santa Catalina de Valencia (1534), primera obra documentada de Joanes, con la "Aprobación por Honorio III de la orden dominica" (obra, tal vez, de Gaspar Requena el Viejo) y la "Ordenación de San Esteban" pintada lustros más tarde para el retablo del santo en el templo de San Esteban de la capital (quizás del obrador de Gaspar Requena el Viejo y sus dos vástagos), particularmente visible en los tronos, los rostros, las vestiduras y los rasgos de ambos pontífices.
} 

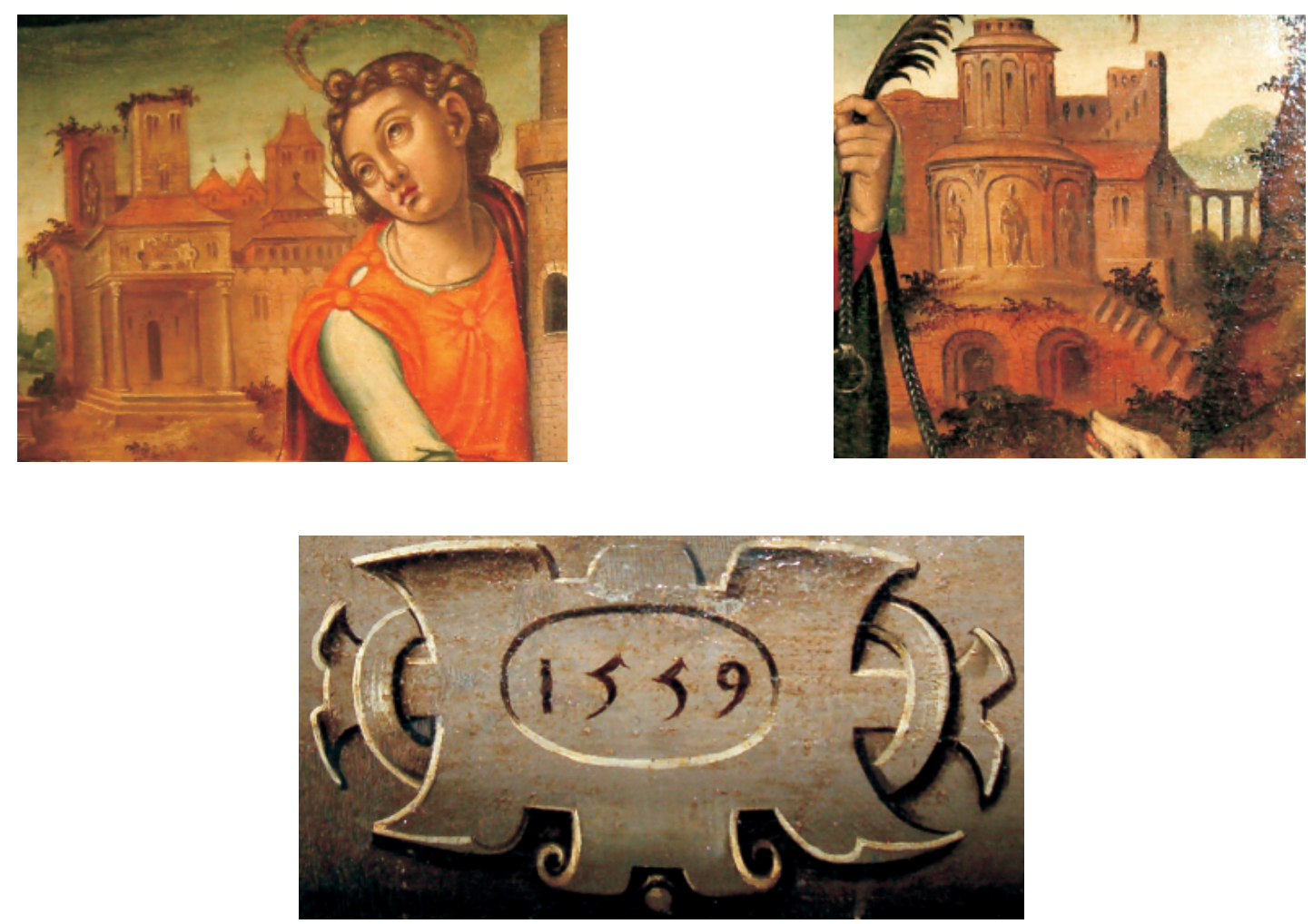

Figs. 22, 23 y 24. Retablo de San Sebastián, San Fabián y San Roque (detalles), 1559. Iglesia parroquial de Montesa.

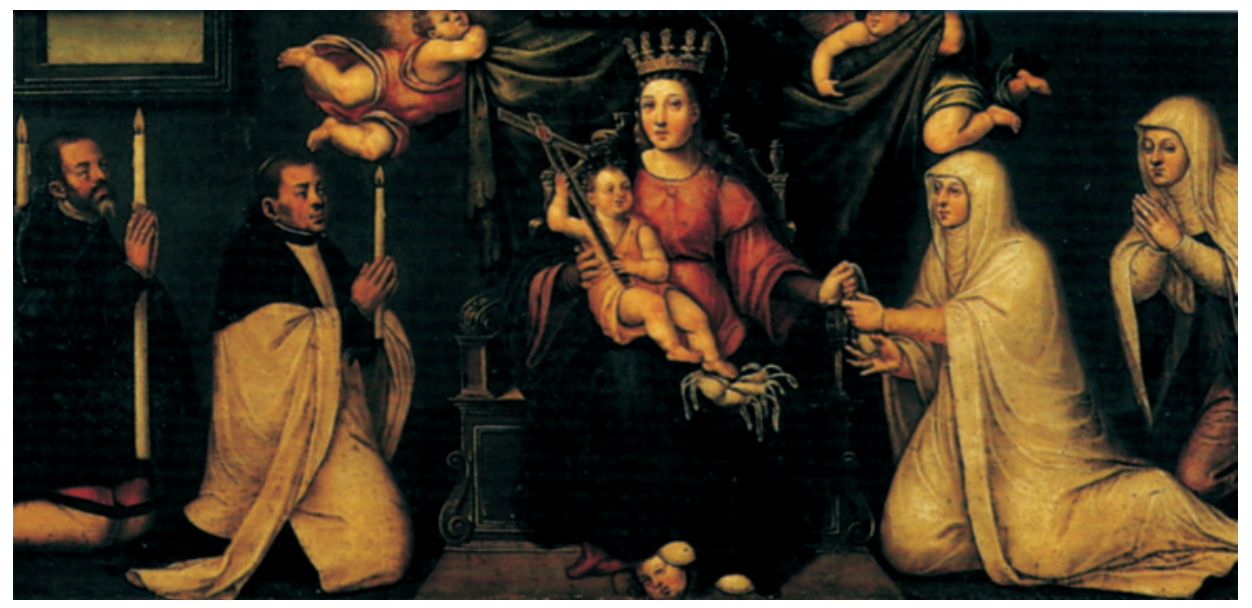

Fig. 25. "Virgen de los Desamparados entregando las dotes a las doncellas huérfanas" (ca. 1589). Basílica de Nuestra Señora de los Desamparados de Valencia. 
Pinturas atribuidas a los Requena

\begin{tabular}{|c|c|c|c|}
\hline CRONOLOGÍA & AUTOR/ES & OBRA & COLECCIÓN \\
\hline ca. 1540 & $\begin{array}{l}\text { G. Requena el Viejo y } \\
\text { Pedro Rubiales }\end{array}$ & $\begin{array}{l}\text { Retablo de "Santa Úrsula y } \\
\text { las once mil vírgenes" }\end{array}$ & $\begin{array}{c}\text { Originalmente en el } \\
\text { convento de la Puridad } \\
\text { (Valencia), actualmente en } \\
\text { el Museo de Bellas Artes } \\
\text { de Valencia }\end{array}$ \\
\hline ca. $1535-40$ & G. Requena el Viejo & $\begin{array}{l}\text { Tablas con los "Pasajes de } \\
\text { la vida de Santo Domingo" }\end{array}$ & $\begin{array}{c}\text { Originalmente en el } \\
\text { convento de Santo } \\
\text { Domingo (Xàtiva), } \\
\text { actualmente en el Museo de } \\
\text { Bellas Artes de Valencia }\end{array}$ \\
\hline ca. $1540-50$ & G. Requena el Viejo & $\begin{array}{c}\text { "Lamentaciones a la muerte } \\
\text { de Cristo" }\end{array}$ & $\begin{array}{l}\text { Procedencia desconocida, } \\
\text { en la actualidad en la } \\
\text { parroquia de Ntra. Sra. de } \\
\text { la Asunción de Foios }\end{array}$ \\
\hline ca. 1556 & $\begin{array}{l}\text { G. Requena el Viejo, G. } \\
\text { Requena el Joven y V. } \\
\text { Requena el Joven (?) }\end{array}$ & $\begin{array}{l}\text { Tabla de la "Ordenación de } \\
\text { San Esteban" en el retablo } \\
\text { homónimo }\end{array}$ & $\begin{array}{l}\text { Originalmente en la } \\
\text { parroquia de San Esteban } \\
\text { (Valencia), actualmente en } \\
\text { el Museo del Prado }\end{array}$ \\
\hline 1556 & G. Requena el Viejo & $\begin{array}{c}\text { Retablo de la "Virgen de } \\
\text { las Virtudes" }\end{array}$ & $\begin{array}{c}\text { Originalmente en la } \\
\text { parroquia de San Esteban } \\
\text { (Valencia) }\end{array}$ \\
\hline 1559 & $\begin{array}{l}\text { G. Requena el Joven } \\
\text { (figs. } 22,23 \text { y } 24 \text { ) }\end{array}$ & $\begin{array}{l}\text { Retablo de "San Sebastián, } \\
\text { San Fabián y San Roque" }\end{array}$ & $\begin{array}{l}\text { Iglesia parroquial de la } \\
\text { Asunción (Montesa) }\end{array}$ \\
\hline ca. $1560-70$ & $\begin{array}{l}\text { G. Requena el Joven y M. } \\
\text { Requena }\end{array}$ & $\begin{array}{c}\text { Retablo de "Santa Bárbara" } \\
\text { (?) }\end{array}$ & $\begin{array}{c}\text { Ermita de San José y } \\
\text { Santa Bárbara (Xàtiva), } \\
\text { actualmente conservadas } \\
\text { entre los Museos de la } \\
\text { Colegiata y de l'Almodí de } \\
\text { la Xàtiva }\end{array}$ \\
\hline 1561 & G. Requena el Joven & $\begin{array}{l}\text { Miniatura para el Llibre de } \\
\text { la Luminaria del Santíssim } \\
\text { Sacrament que comença } \\
\text { l'any } 1561 \text { i acaba en } 1644\end{array}$ & Colegiata (Xàtiva) \\
\hline $7-V-1565$ & G. Requena el Joven & Retablo mayor & $\begin{array}{l}\text { Convento de Corpus Christi } \\
\text { (Lluxent) }\end{array}$ \\
\hline ca. 1574 & $\begin{array}{l}\text { G. Requena el Joven, V. } \\
\text { Requena el Viejo, Miguel } \\
\text { Requena y Cristóbal } \\
\text { Llorens (o V. Requena el } \\
\text { Joven) }\end{array}$ & $\begin{array}{l}\text { Retablo de "San Sebastián, } \\
\text { San Fabián y San Roque" }\end{array}$ & $\begin{array}{c}\text { Ermita de San Sebastián } \\
\text { (Vallada), actualmente en } \\
\text { el templo de Nuestra Sra. } \\
\text { de la Asunción y la casa } \\
\text { abadía }\end{array}$ \\
\hline ca. $1575-85$ & $\begin{array}{l}\text { G. Requena el Joven y V. } \\
\text { Requena el Joven }\end{array}$ & Retablo de almas & $\begin{array}{c}\text { Iglesia parroquial de San } \\
\text { Bartolomé (Agulent) }\end{array}$ \\
\hline
\end{tabular}




\begin{tabular}{|c|c|c|c|}
\hline CRONOLOGÍA & AUTOR/ES & OBRA & COLECCIÓN \\
\hline ca. $1575-85$ & $\begin{array}{l}\text { G. Requena el Joven y V. } \\
\text { Requena el Joven }\end{array}$ & $\begin{array}{c}\text { Retablo de "Santiago } \\
\text { Apóstol" }\end{array}$ & Parroquial de Bocairent \\
\hline $17-X-1582$ & G. Requena el Joven & Pinturas y tablas & Hospital General (Valencia) \\
\hline 1589 & V. Requena el Joven & Retablo de "San Jerónimo" & $\begin{array}{l}\text { Monasterio de San Miguel } \\
\text { de los Reyes (Valencia), } \\
\text { actualmente dos de sus } \\
\text { tablas en el Museo de } \\
\text { Bellas Artes de Valencia }\end{array}$ \\
\hline ca. 1589 & $\begin{array}{l}\text { V. Requena el Joven } \\
\text { (fig. 25) }\end{array}$ & $\begin{array}{c}\text { "Virgen de los } \\
\text { Desamparados entregando } \\
\text { las dotes a las doncellas } \\
\text { huérfanas" }\end{array}$ & $\begin{array}{c}\text { Basílica de Nuestra Señora } \\
\text { de los Desamparados } \\
\text { (Valencia) }\end{array}$ \\
\hline ca. 1590 & V. Requena el Joven (?) & Retablo de la "Santa Faz" & $\begin{array}{l}\text { Monasterio de Clarisas de } \\
\text { la Santa Faz (Alicante) }\end{array}$ \\
\hline ca. $1590-95$ & V. Requena el Joven & "Piedad" & $\begin{array}{c}\text { Hospital General } \\
\text { (Valencia), actualmente en } \\
\text { la Diputación Provincial }\end{array}$ \\
\hline 1592 & V. Requena el Joven & $\begin{array}{l}\text { Mural con el "Braç } \\
\text { Eclesiàstic" }\end{array}$ & $\begin{array}{c}\text { Sala Nova del palacio de la } \\
\text { Generalitat }\end{array}$ \\
\hline 1594 & V. Requena el Joven & Retablo de "Santa Ana" & $\begin{array}{l}\text { Monasterio de San Miguel } \\
\text { de los Reyes (Valencia), } \\
\text { actualmente una de sus } \\
\text { tablas en el Museo de } \\
\text { Bellas Artes de Valencia }\end{array}$ \\
\hline ca. 1594 & V. Requena el Joven & Retablo de "San Roque" & $\begin{array}{c}\text { Convento de San Juan de } \\
\text { la Ribera (Valencia), cedido } \\
\text { por el Ayto. de Valencia al } \\
\text { Monasterio del Puig }\end{array}$ \\
\hline ca. 1594 & V. Requena el Joven & "Trinidad" & $\begin{array}{c}\text { Museo de Bellas Artes } \\
\text { de Valencia, cedido al } \\
\text { Monasterio del Puig }\end{array}$ \\
\hline ca. $1595-1600$ & V. Requena el Joven & $\begin{array}{c}\text { Retablo de la "Virgen de } \\
\text { Loreto" }\end{array}$ & $\begin{array}{c}\text { Antiguo Hospital Municipal } \\
\text { (Benissa), actualmente en } \\
\text { el Museo Municipal de } \\
\text { Benissa }\end{array}$ \\
\hline 1597 & V. Requena el Joven & Retablo de "San Silvestre" & Ayuntamiento de Alzira \\
\hline ca. 1597 & V. Requena el Joven & $\begin{array}{c}\text { "Santiago el Mayor y San } \\
\text { Pablo" }\end{array}$ & $\begin{array}{l}\text { Procedencia desconocida, } \\
\text { actualmente en el Museo de } \\
\text { Bellas Artes de Valencia }\end{array}$ \\
\hline ca. 1600 & V. Requena el Joven & "San Vicente Ferrer" & $\begin{array}{l}\text { Ermita de San Vicente } \\
\text { Ferrer (Teulada) }\end{array}$ \\
\hline
\end{tabular}

Fecha de recepción: 4-VI-2007

Fecha de aceptación: 15-XII-2007 